Sains Malaysiana 49(11)(2020): 2699-2714

http://dx.doi.org/10.17576/jsm-2020-4911-09

\title{
Enantiomeric Separation of Azole Antifungal Compounds using Chromatographic and Electrophoretic Techniques: A Mini Review
}

(Pemisahan Enantiomerik Sebatian Antikulat Azol menggunakan Teknik Kromatografi dan Elektroforetik: Suatu Ulasan Mini)

\begin{abstract}
Nurul Raihana Binti AzHari, Boon Yih Hui, Nur NadhiRah MOHAMAD Zain, Faiz BukHari Mohd SuAH, SHARIFAH MOHAMAD, NOORFATIMAH YAHAYA* \& MUGgUNDHA RAOOV*
\end{abstract}

\section{ABSTRACT}

The separation of azole antifungal chiral compounds has gaining much interests since 1980's as they possess different biological, pharmaceutical, and pharmacokinetic behaviors at various toxicity levels. Numerous studies have looked into this subject matter, and therefore, this review presents an overview on different chiral separation techniques that have been developed such as liquid chromatography (LC), gas chromatography (GC), supercritical fluid chromatography (SFC), and capillary electrophoresis (CE). This comprehensive review also discusses the mechanisms of the developed analytical methods such as preparation techniques and optimization parameters towards the enantioseparation performances as well as their advantages and drawbacks. Lastly, the conclusion and future directions of the chiral separation, particularly for azole compounds are provided accordingly.

Keywords: Antifungal compounds; azole; capillary electrophoresis; chiral separation; chromatographic analysis

ABSTRAK

Pemisahan sebatian kiral antikulat azol telah menarik perhatian sejak tahun 1980 kerana ia mempunyai sifat biologi, farmaseutik dan farmakokinetik pada tahap ketoksikan yang berbeza. Oleh itu, kajian ini membentangkan gambaran keseluruhan mengenai teknik pemisahan kiral yang berbeza seperti kromatografi cecair (LC), kromatografi gas (GC), kromatografi cecair supergentingan (SFC) dan elektroforesis rerambut (CE). Kajian komprehensif ini juga membincangkan mekanisme bagi kaedah analisis yang maju seperti teknik penyediaan dan parameter pengoptimuman ke arah persembahan pemisahan enantio serta kelebihan dan kekurangannya. Akhir sekali, kesimpulan dan hala tuju masa depan dalam pemisahan kiral, terutamanya bagi sebatian azol diberikan dengan sewajarnya.

Kata kunci: Analisis kromatografik; azol; pemisahan kiral; rerambut elektroforesis; sebatian antikulat

GRAPHICAL ABSTRACT

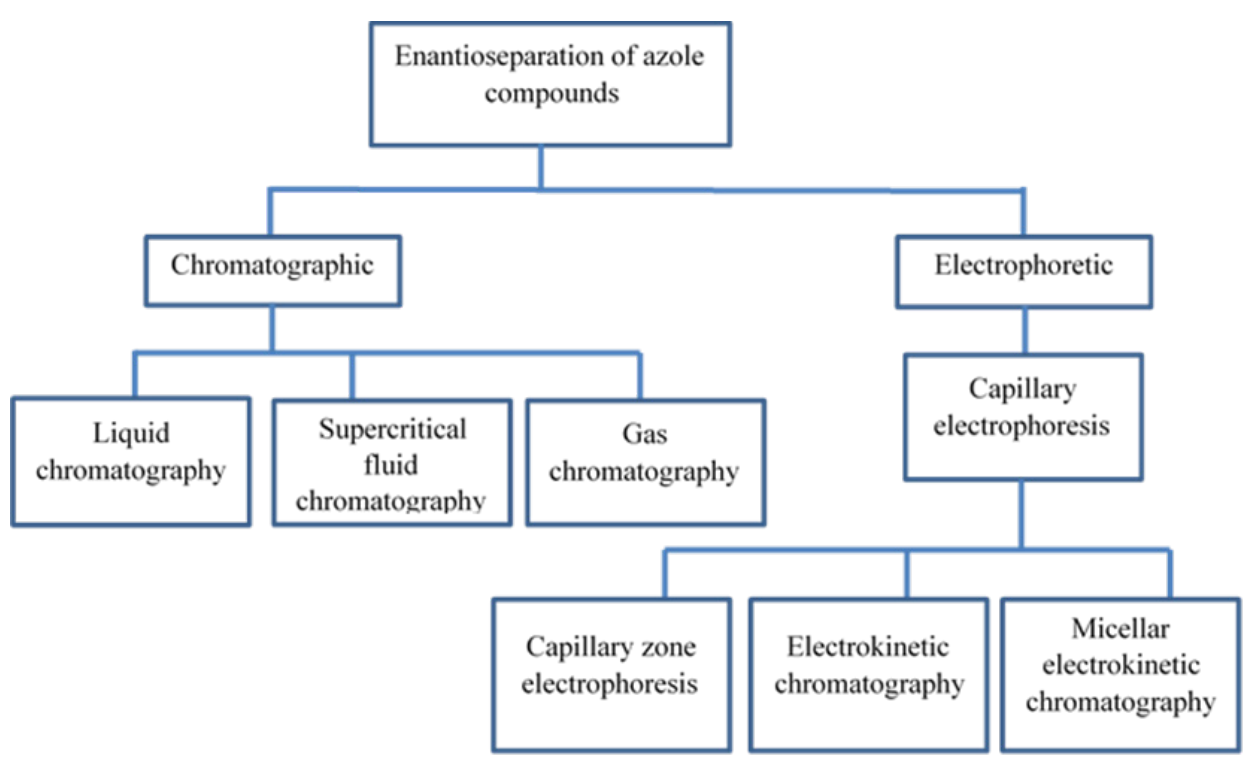




\section{INTRODUCTION}

\section{AZOLE ANTIFUNGAL COMPOUNDS}

Azole antifungal compounds are the largest class of synthetic antimycotics. Their fungicidal properties have been discovered in 1944, and during 1958, chlormidazole was first introduced and penetrated the market (Woolley 1944). Nevertheless, this initial compound was limited solely for topical application as they have been sparked with a number of issues such as high toxicity and narrow pharmacological activity. For example, they were unsuitable to treat patients with acquired immunodeficiency syndrome (AIDS) and those who were undergoing anticancer chemotherapy or suffered from organ transplant (Crego et al. 2001). As such, in-depth investigations were carried out to promote the registration of a variety of imidazolic drugs, for instance, ketoconazole, miconazole, econazole, clotrimazole, isoconazole, sulconazole, tioconazole, and bifonazole (Benfield \& Clissold 1988; Como \& Dismukes 1994). Later, an aromatic heterocyclicbased antifungal agent called triazoles had been reported to exhibit wider antifungal activity spectra, better safety profile, and higher efficacy, in comparison to other previously used imidazole derivatives (Shalini et al. 2011). The first-generation of triazole derivatives, such as fluconazole and itraconazole, led to a real breakthrough in the prevention and treatment of invasive fungal infections, which can be applied through both parenteral and oral routes, while terconazole is available in topical dosage form. In the 1990s, the second-generation of triazoles was introduced including voriconazole, ravuconazole, and posaconazole were applied as the primary treatment for invasive pathogen particularly, Aspergillus sp. (Maertens 2004). Due to the improvised pharmacology activity and lower toxicity, azole antifungal agents are therefore being used extensively to date. At present, studies have begun to probe into more triazole compounds in advanced investigation for ravuconazole, isavuconazole, and albaconazole, as well as their pharmacology, spectrum, clinical efficacy, and shortcomings (Aperis \& Mylonakis 2006; Girmenia 2009). Generally, azole compounds inhibit the steroid demethylation and the biosynthesis of a critical component of fungal membrane called ergosterol by blocking a cytochrome P450-dependent enzyme: lanosterol 14- $\alpha$-demethylase which is crucial for the conversion of lanosterol to ergosterol. Lack of ergosterol and accumulation of lanosterol-14- $\alpha$-demethylase will increase the membrane permeability and lead to disruption of several enzymes in the membrane, such as chitin synthase (Maertens 2004). This does not only inhibit its DNA replication, but also distracts cell growth that causes the death of yeast and fungi. Azoles also decrease the adhesion potential of pathogen cells to host tissues and impede the transformation of yeasts to mycelial form (Ghannoum \& Rice 1999). Therefore, they are widely applied as veterinary drugs (Bhanderi et al. 2009), as fungicides in agriculture (Brauer et al. 2019), and as antifungal agents for both humans and animals (Scorzoni et al. 2017).

\section{AZOLE AS CHIRAL COMPOUNDS}

Most azole compounds are chiral in which four different atoms or groups are attached to their carbon atoms (chiral or stereogenic center) to form enantiomer pairs that are non-superimposable mirror images. In the pharmaceutical and drug industries, chirality has emerged to be a rather serious matter since each enantiomer may differ in terms of their pharmaceutical, pharmacokinetic or toxicological properties. One enantiomer may be active and potent, while the other can end up being inactive, or causing side effects to consumers and acts as an antagonist. For example, the bioactivities displayed by $(2 \mathrm{R}, 4 \mathrm{~S})$ - and (2S, 4R)ketoconazole and $(2 \mathrm{~S}, 4 \mathrm{~S})-,(2 \mathrm{R}, 4 \mathrm{R})-,(2 \mathrm{R}, 4 \mathrm{~S})-$ and $(2 \mathrm{~S}$, $4 \mathrm{R}$ )-difeconazole have been reported to differ among the enantiomers (Anwar-Mohamed et al. 2016; Dilmaghanian et al. 2004; Dong et al. 2013). Apart from that, there is another study claimed some enantiomers such as (R, R)and (S, S)-genaconazole, exhibit equivalent bioavailability and pharmacokinetic profiles between the enantiomers (Kim et al. 2002). Nevertheless, report that describe the toxicity profiles for most chiral antifungal drugs are lack and scarce due to the limited amounts of enantiomerically pure compounds for analyses in stereoselective biological and toxicological trials (Cirilli et al. 2002). In fact, enantioselective synthesis is impractical, complicated, and costly since it consists of multiple of steps, requires expensive, highly pure optically active compounds to avoid any contamination and some conditions must be strictly taken into considerations such as temperature, $\mathrm{pH}$ and reaction time to ensure a good yield (Gala et al. 1996). In addition, there is also a requirement on the drug production industries to specify the enantiomeric purity for all the optically active compounds prior to marketing. Subsequently, the separation of racemic mixtures started to receive attention among researchers.

To the best of authors' knowledge, review articles that discuss specifically on the enantioseparation of azole antifungal compounds has not yet been reported in literature. Hence, this review article aimed to summarize the past studies on chiral separations of azole compounds. The potentials and limitations of all chromatographic and electrophoretic methods are addressed as well. Therefore, this review does not only offer an overview of azole chiral separation techniques, but also provides a general approach for various chiral analysis. 


\section{ENANTIOSEPARATION METHODS}

Chiral separation of drugs and pharmaceutical products using chromatographic and electrophoretic methods has gained much interests since past decades (Bounoua et al. 2016; Gübitz 1990; Mangelings \& Vander Heyden 2008; Nishi \& Terabe 1995; Otsuka \& Terabe 2000; PérezFernández et al. 2011; Ye et al. 2009). The principles of chiral separation coupled with these methods and their developments have been elaborated in a systematic manner by Gübitz and Schmid (2008) geelectrophoretic methods is their separation capabilities that represent in resolution (Rs).

In general, there are two methods (direct and indirect) to separate the enantiomers. The indirect method is performed by adding chiral derivatizing reagents or additives to convert the enantiomers into diastereomers followed with achiral separation using high performance liquid chromatography (HPLC), capillary electrophoresis (CE), and gas chromatography (GC) analysis. For example, the first indirect method to enantioseparate the triazole fungicides using GC was reported by Burden et al. (1987) by adding acid chlorides to triazole compounds to form diastereoisomeric esters in which all enantiomers were resolved in less than $3.8 \mathrm{~min}$. Later, another investigation was carried out on the enantioseparation of simeconazole in vegetables, fruits, and cereals by using the QuEChERS (quick, easy, effective, rugged, and safe) methods to eliminate interferences in samples prior to GC analysis (Li et al. 2011). Despite the low cost of achiral columns, the indirect method is time-consuming and projects high probability of racemization, thus it is less preferred by the researchers (Ilisz et al. 2008).

The direct method, on the other hand, is applied by adding chiral selector or additives into the mobile phase of HPLC or background electrolyte (BGE) of CE and the separation is performed using chiral stationary phases (CSPs). Among the many chromatographic methods, HPLC is the most used techniques as it has certified and established procedures for identification, separation, and quantitation of bioactive compounds using CSPs. While $\mathrm{GC}$ is employed for highly volatile and thermally stable chiral compounds. Other chromatographic methods such as sub- and supercritical fluid chromatography (sub-SFC and SFC) also have been proven to successfully separate chiral compounds and possess high potential to replace chiral HPLC since carbon dioxide $\left(\mathrm{CO}_{2}\right)$ as a supercritical fluid is cheap, lower toxicity, and offers better efficacy with sharper peaks and improved peak resolution. Apart from that, electrophoretic method of $\mathrm{CE}$ also has been discussed in this review as this technique is rapid, flexible, highly efficient, generates sharper peaks, less solvent and chiral selector consumption. Furthermore, 'plug flow' is created as the velocity of liquid is nearly uniform within the narrow confines of capillary in $\mathrm{CE}$, as compare to the parabolic flow in HPLC that creates velocity profiles across the tube diameter, thus minimizes the peak broadening effect.

\section{Chromatographic Methods}

\section{LIQUID CHROMATOGRAPHY (LC)}

The chiral resolution of azole compounds using LC, including HPLC and ultra-performance liquid chromatography (UPLC) has attained great interests in the field of separation science. Various procedures and parameters have been performed on the enantioseparation of chiral azole compounds, as presented in Table 1. For example, many racemates have been separated by employing various CSPs, such as polysaccharides-based CSPs, macrocyclic antibiotic-based CSPs, pirkle-type CSPs, and CD-based CSPs, mostly ranging at 100-250 $\mathrm{mm}$ in length with an internal diameter of $4.6 \mathrm{~mm}$. CSPs usually produced by small molecule of chiral compounds or chiral polymers attached onto the silica surface. Since 1990s, many reported works have highlighted the applications, the advantages, and the drawbacks of CSPs for different chiral compounds (Aboul-Enein \& Bakr 1998; Armstrong 1984; Cai et al. 2005; Cirilli et al. 2002; Ghanem et al. 2006; Gübitz 1990; Ilisz et al. 2006; Lämmerhofer 2010; Okamoto \& Kaida 1994; Sellergren 2001; Suedee et al. 1999; Tachibana \& Ohnishi 2001; Yashima 2001; Zhou et al. 2010). Among these CSPs, the polysaccharide-based, especially 3,5-dimethylphenylcarbamate of amylose and cellulose has stand to be the most commonly CSP being applied due to their broad applicability and enantioselectivity, mostly dominating by $\pi$ - $\pi$, dipole-dipole, and hydrogen bonding interactions (Pan et al. 2006; Pérez-Fernández et al. 2011). In fact, there are also some comparison studies on the preparation and applications of these amylose and cellulose CSPs (Aboul-enein \& Ali 2004; Yamamoto \& Okamoto 2004). Among them, the structure analogue of more helical and well-defined grooves of amylose suggest greater application in chiral separation, when compared to cellulose that possesses linear and rigid structure (Ali et al. 2009).

The other parameter, such as mobile phase composition can be manipulated in order to improve the resolution as shown in Table 1. Generally, the mobile phase composition affects the interaction of analytes in the column, thus, causing shorter or longer analysis time, apart from influencing the chiral resolution. This parameter was examined by Mskhiladze et al. (2013) and they found that the enantiomer elution order (EEO) can change as the mobile phase composition varies. Besides, Ali et al. (2009) also studied the effect of varied 
compositions of acetonitrile-water (ACN-water) as mobile phase, whereby the results showed that increase in the amount of ACN reduced the bonding between racemates and CSP. Nevertheless, broad peak with high resolution was obtained as the amount of ACN decreased probably due to stronger magnitude of bonding between water and analytes.

It is interesting to note that the alcoholic organic modifiers such as ethanol and 2-propanol also play role in the resolution. For this, Cheng et al. (2013), had reported the enhancement of peak resolution in the presence of polar modifiers, however, it dropped as the concentration of polar modifier increased. This could be explained by the competition effect between the polar modifier and analytes that interact with the CSP. To sum up, chiral separation not only depends on the polarity and viscosity of organic modifiers, but also rely on their structure, size, and bulkiness which will affect the chiral cavity (Lv \& Zhou 2011; Wang et al. 2005).

TABLE 1. HPLC separation conditions for enantioseparation of

azole compounds (a) Polysaccharides-based CSPs, (b) macrocyclic antibiotic-based CSPs, (c) Pirkle-type CSPs, and (d) CD-based CSPs

(a) Polysaccharides-based CSPs

\begin{tabular}{|c|c|c|c|c|c|}
\hline Analyte(s) & LC/Detection & Stationary phase (s) & Mobile phase & Resolution & Reference \\
\hline Propiconazole & HPLC-DAD & $\begin{array}{l}\text { Chiralpak }{ }^{\circledR} \text { OD-H, } \\
\text { Chiralpak }{ }^{\circledR} \text { AS-H, } \\
\text { Chiralpak }{ }^{\circledR} \text { AD-H, } \\
\text { Chiralcel }{ }^{\circledR} \text { OJ-H, } \\
\text { ChromegaChiral CCA }\end{array}$ & n-hexane/EtOH $(95: 5 \mathrm{v} / \mathrm{v})$ & $0.63-6.67$ & (Cheng et al. 2013) \\
\hline $\begin{array}{l}\text { Diniconazole, uniconazole, } \\
\text { paclobutrazole }\end{array}$ & HPLC-UV & ADMPC & $\begin{array}{l}\text { Hexane/butanol (90:10 } \\
\text { v/v) }\end{array}$ & n.s-7.70 & (Lv \& Zhou 2011) \\
\hline $\begin{array}{l}\text { Bifonazole, econazole, } \\
\text { enilconazole, itraconazole, } \\
\text { ketoconazole, miconazole, } \\
\text { metomidate, ornidazole, } \\
\text { sulconazole, terconazole }\end{array}$ & HPLC-UV & $\begin{array}{l}\text { ADMPC, Lux amylose-2, } \\
\text { Lux cellulose-1, Lux } \\
\text { cellulose-2, Lux } \\
\text { cellulose-3, Lux } \\
\text { cellulose-4 }\end{array}$ & $\begin{array}{l}\mathrm{MeOH}, \mathrm{EtOH}, \\
\text { 2-propanol, diethylamine, } \\
\text { (various ratios) }\end{array}$ & n.s- 9.50 & $\begin{array}{l}\text { (Mskhiladze et al. } \\
\text { 2013) }\end{array}$ \\
\hline Voriconazole & HPLC-UV & Chiralcel ${ }^{\circledR}$ OD-H & n-hexane/ EtOH $(9: 1 \mathrm{v} / \mathrm{v})$ & 3.0 & $\begin{array}{l}\text { (Nagarjuna et al. } \\
\text { 2007) }\end{array}$ \\
\hline Fenticonazole & HPLC-UV & Chiralcel ${ }^{\circledR} \mathrm{OD}-\mathrm{H}$ & $\begin{array}{c}\text { n-hexane/ 2-propanol } \\
(92: 8 \mathrm{v} / \mathrm{v})\end{array}$ & n.s-1.44 & $\begin{array}{l}\text { (Quaglia et al. } \\
\text { 2002) }\end{array}$ \\
\hline $\begin{array}{l}\text { Econazole, miconazole, } \\
\text { sulconazole }\end{array}$ & HPLC-UV & $\begin{array}{c}\text { Chiralpak AD, Chiralpak } \\
\text { AS, and Chiralpak AR }\end{array}$ & $\begin{array}{c}\text { Hexane/ 2-propanol/ } \\
\text { diethyl amine (400:99:1 } \\
\text { v/v/v) }\end{array}$ & n.s-5.68 & $\begin{array}{c}\text { (Aboul-Enein \& Ali } \\
\text { 2001) }\end{array}$ \\
\hline Ketoconazole & HPLC-UV & Chiralpak AD & $\begin{array}{c}\text { Hexane/ 2-propanol/ } \\
\text { diethyl amine (70:20:10 } \\
\text { v/v/v) }\end{array}$ & 2.30 & $\begin{array}{c}\text { (Hamdy \& Brocks } \\
\text { 2008) }\end{array}$ \\
\hline $\begin{array}{l}\text { Econazole, miconazole, } \\
\text { isoconazole, sulconazole }\end{array}$ & HPLC-UV & AmyCoat RP column & $\begin{array}{c}\text { Water/ACN }(40: 60 \mathrm{v} / \mathrm{v}) \\
\text { water/ACN/ acetic acid/ } \\
\text { DEA }(50: 50: 0.4: 0.02 \\
\text { v/v/v/v) }\end{array}$ & $1.29-1.97$ & (Ali et al. 2009) \\
\hline $\begin{array}{l}\text { Myclobutanil, } \\
\text { paclobutrazol, tebuconazole, } \\
\text { imizalil, diniconazole and } \\
\text { uniconazole }\end{array}$ & HPLC-DAD & ADMPC & $\begin{array}{c}\text { n-hexane: isopropanol } \\
(90: 10 \mathrm{v} / \mathrm{v})\end{array}$ & $0.77-5.73$ & (Wang et al. 2008) \\
\hline Ketoconazole & HPLC-DAD & $\begin{array}{c}\text { Chiralpak }{ }^{\circledR} \text { IA, } \\
\text { chiralpak }{ }^{\circledR} \text { IB, } \\
\text { chiralpak } ® \text { IC column }\end{array}$ & $\begin{array}{c}\text { EtOH/water }(1: 1,8: 2 \mathrm{v} / \mathrm{v}) \\
\mathrm{MeOH}(100 \%) \& \mathrm{EtOH} \\
(100 \%)\end{array}$ & 4.99 & $\begin{array}{l}\text { (Andrade et al. } \\
\text { 2015) }\end{array}$ \\
\hline
\end{tabular}


Econazole, miconazole, sulconazole

Econazole, miconazole, sulconazole

Tebuconazole, hexaconazole, myclobutanil, diniconazole, uniconazole, uniconazole, paclobutrazol, triadimenol

Diniconazole, tebuconazole, hexaconazole, triadimefon, flutriafol

Uniconazole

Tetraconazole,

febuconazole,

epoxiconazole,

diniconazole, hexaconazole, triadimefon, paclobutrazol, myclobutanil

Diniconazole, fenbuconazole,

hexaconazole, flotriafol, myclobutanil, penconazole, prothioconazole, simeconazole, tebuconazole, tetraconazole, triadimefon, uniconazole, diclobutrazol, epoxiconazole, paclobutrazol, biternatol, bromuconazole, cyproconazole, difenoconazole, popiconazole, triadomenol
HPLC-UV

Chiralcel OD, Chiralcel OJ, Chiralcel OB,

Chiralcel OK, Chiralcel OC, Chiralcel OF

$$
\text { HPLC-UV }
$$

L-proline-copper (II) complex bonded with silica, Chiralpak WH column

HPLC- UV

CTB, CTMB, CTPC, and CDMPC diethyl amine (400:99:1

CDMPC detector

HPLCphotodiodearray (PDA) and circular dichroism (CD)

UPLC-MS-MS

Chiral OD-RH

HPLC/MS/MS
Lux cellulose-1, Lux
Cellulose-2, Lux
Cellulose-3, and Lux Amylose-2

Mixture of ACN-2mM ammonium acetate: water $(55: 45, \mathrm{v} / \mathrm{v})$
Hexane/ 2-propanol/ diethylamine (425:74:1

$$
\mathrm{v} / \mathrm{v} / \mathrm{v})
$$

Hexane/2-propanol/ $\mathrm{v} / \mathrm{v} / \mathrm{v})$

Hexane-iso-propanol / hexane-n-propanol (various ratios)

0.17-3.90 (Aboul-Enein \& Ali 2002)

1.10-2.42 (Aboul-Enein \& Ali 2001)

$0.31-15.59$

(Pan et al. 2006)

n-hexane: isopropanol

$1.62-2.46$

(Wang et al. 2005) (various percentages)

(b) Macrocyclic antibiotic-based CSPS

\begin{tabular}{lcccc}
\hline \multicolumn{1}{c}{ Analyte(s) } & LC/Detection & Stationary phase (s) & Mobile phase & Resolution \\
\hline $\begin{array}{l}\text { Econazole, ketoconazole, } \\
\text { miconazole, tebuconazole, } \\
\text { propiconazole }\end{array}$ & HPLC-MS-MS & HSA and AGP & ACN/ ultrapure water & n.s-2.1 \\
$(10: 90 \mathrm{v} / \mathrm{v})$ & (Huang et al. 2012) \\
$\begin{array}{l}\text { Triadimefon, propiconazol, } \\
\text { difenoconazole }\end{array}$ & HPLC-UV & Emamectin-based CSP & $\begin{array}{l}\text { Isopropanol in n-hexane } \\
\text { with various proportions }\end{array}$ & N.A \\
\hline
\end{tabular}


(c) Pirkle type CSPs

\begin{tabular}{|c|c|c|c|c|c|}
\hline Analyte(s) & LC/Detection & Stationary phase (s) & Mobile phase & Resolution & Reference \\
\hline $\begin{array}{l}\text { Tebuconazole, } \\
\text { hexaconazole, } \\
\text { myclobutanil, diniconazole, } \\
\text { uniconazole, uniconazole, } \\
\text { paclobutrazol, triadimenol }\end{array}$ & HPLC- UV & $(\mathrm{S}, \mathrm{S})-$ Whelk O1 & $\begin{array}{c}\text { Hexane-iso-propanol / } \\
\text { hexane-n-propanol (various } \\
\text { ratios) }\end{array}$ & $0.31-15.59$ & (Pan et al. 2006) \\
\hline $\begin{array}{l}\text { Tetramisole, miconazole, } \\
\text { paclobutrazol }\end{array}$ & HPLC-DAD & $\begin{array}{l}\text { 4-(3,5-dinitrobenzamido) } \\
\text { tetrahydrophenanthrene, } \\
\text { covalently bonded } \\
\text { through monofunctional } \\
\text { linkage, }(\mathrm{S}, \mathrm{S})-\text { Whelk-O1 } \\
\text { column and CDMPC } \\
\text { column }\end{array}$ & $\begin{array}{l}\text { Hexane/ 2-propanol/ diethyl } \\
\text { amine (various ratios) }\end{array}$ & n.s- 6.72 & (Cai et al. 2005) \\
\hline
\end{tabular}

(d) CD-based CSPs

\begin{tabular}{|c|c|c|c|c|c|}
\hline Analyte(s) & LC/Detection & Stationary phase (s) & Mobile phase & Resolution & Reference \\
\hline Tioconazole & HPLC-UV & $\begin{array}{c}\text { Astec cyclobond I } \\
\beta \text {-cyclodextrin column }\end{array}$ & $\begin{array}{l}\text { Acetic acid/ triethanolamine } \\
(100: 3.2 \mathrm{v} / \mathrm{v}) \& \text { acetic acid/ } \\
\text { triethylamine }(100: 3.5 \mathrm{v} / \mathrm{v})\end{array}$ & $>1.0$ & $\begin{array}{c}\text { (Ferguson et al. } \\
1996)\end{array}$ \\
\hline
\end{tabular}

"n.s" means no separation, N.A means not available

\section{GAS CHROMATOGRAPHY (GC)}

$\mathrm{GC}$ has been widely used to analyze volatile chiral compounds that are thermally stable and easily vaporized. However, most of the chiral azole compounds are less volatile and unstable at high temperature. Thus, these properties had limit the number of study regarding to the chiral separation by using GC. The direct separation of azole compounds in GC normally involves CSPs that consists of amino acid derivatives and diamides, chiral metallic complexes, and cyclodextrin (CD) derivatives. The separation mechanism is usually due to the formation of dynamic diastereomeric complex between CSP and enantiomers through various interactions such as hydrogen bonding, $\pi-\pi$ interaction, inclusion complex, dipole-dipole, and ionic interactions.

For example, Bicchi et al. (1999) demonstrated the application of various derivatized CDs as GC stationary phases coupled with flame ionization detector (FID) on 20 chiral azole pesticides. During the study, triadimefon was unable to be resolved for all the columns investigated, while 2,3-di-O-acetyl-6-O-thexyldimethylsilyl- $\gamma$ cyclodextrin (ACTHDMS- $\gamma$-CD) and 2,3-di-O-ethyl-6O-thexyldimethylsilyl- $\gamma$-cyclodextrin (ETTHDMS- $\gamma$-CD) with PS-086 as diluting phase displayed better resolution (Rs for imizalil:2.9, penconazole:3.6, tebuconazole:0.1 for ACTHDMS- $\gamma-C D$, and hexaconazole:1.2, imizalil:0.3, myclobutanyl:1.1, penconazole:0.3, propiconazole: 1.4 for ETTHDMS- $\gamma-C D$ ), as compared to those that used native $\beta$-CD where none of the azole compounds was resolved. This was probably attributed to the small cavity of native $\beta$-CD which are unable to fit the bulky structure of azole compounds as compared to bigger cavity of $\gamma-\mathrm{CD}$. Hence, no resolution performance.

\section{SUB- AND SUPERCRITICAL FLUID CHROMATOGRAPHY (SUB-SFC AND SFC)}

Recently, SFC has emerged as a powerful alternative technique for chiral separation which use supercritical fluid as eluent. Generally, supercritical fluid was obtained when a substance reaches physico-chemical state, in which the temperature and pressure are increased at or above its thermodynamic critical point. For this, $\mathrm{CO}_{2}$ that exhibits low critical pressure and temperature has become a popular choice of supercritical fluid in SFC. Moreover, $\mathrm{CO}_{2}$ is an inert gas, safer to human, and can be re-purified after analysis, thus can reduce the production cost.

Nonetheless, the use of pure $\mathrm{CO}_{2}$ as eluent sometimes failed to resolve all the compounds as it tends to strongly retains at the stationary phase for a longer time and reduces the peak resolution (Bernal et al. 2000). The authors discovered that the ketoconazole was strongly retained on the amylose-based column and hence, high percentage of 
alcoholic modifier was employed to increase the solvent strength and to enhance the resolution. This was further supported by Toribio et al. (2014) which claimed that the presence of organic modifier will compete with analyte to interact with the stationary phase (through hydrogen bonding) and by modifying the chiral cavity indirectly improves the chiral separation of azole compounds and reduces the retention time. However, their concentration was controlled below $50 \%$ as higher concentration of modifiers can alter the critical point of $\mathrm{CO}_{2}$, thus, they are no longer exist in sub- or supercritical state. Apart from that, the column temperature, pressure and polarity of the organic modifiers also have been studied since they can affect the viscosity and density of the mobile phase as well as the elution order, retention time and resolution performance (Del Nozal et al. 2003). Table 2 summarized the separation conditions of azole compounds by SFC technique.

TABLE 2. SFC separation mode for chiral azole compounds

\begin{tabular}{|c|c|c|c|c|c|}
\hline Analyte(s) & LC/Detection & Stationary phase (s) & Optimum condition & Resolution & Reference \\
\hline Ketoconazole & SFC-DAD & $\begin{array}{c}\text { Chiralpak AD } 250 \times 4.6 \\
\text { mm, packed with the } \\
\text { 3,5-dimethylphenylcarbamate } \\
\text { derivative of amylose coated on } \\
10 \mathrm{~mm} \text { silica-gel support }\end{array}$ & $\begin{array}{l}30 \% \text { ethanol (containing } \\
0.1 \% \text { triethylamine and } 0.1 \% \\
\text { trifluoroacetic acid), pressure } \\
\text { of } 300 \text { bar, a temperature of } 35 \\
{ }^{\circ} \mathrm{C} \text { and a flow-rate of } 3 \mathrm{~mL} / \mathrm{min}\end{array}$ & 4.29 & $\begin{array}{l}\text { (Bernal et } \\
\text { al. 2000) }\end{array}$ \\
\hline $\begin{array}{l}10 \text { triazoles and } \\
\text { eight imidazoles }\end{array}$ & SFC-DAD & $\begin{array}{c}\text { Chiralpak AD } 250 \times 4.6 \mathrm{~mm} \text {, } \\
\text { packed with the } 3,5- \\
\text { dimethylphenylcarbamate } \\
\text { derivative of amylose, coated on } \\
10 \mu \mathrm{m} \text { silica-gel support }\end{array}$ & $\begin{array}{l}20 \% \text { of alcohol type modifiers } \\
\text { with pressure of } 20 \mathrm{MPa} \text {, a } \\
\text { temperature of } 35{ }^{\circ} \mathrm{C} \text { and flow } \\
\text { rate at } 2 \mathrm{~mL} / \mathrm{min}\end{array}$ & $\begin{array}{l}\text { 0-11.0 for } \\
\text { triazoles and } \\
0-12.5 \text { for } \\
\text { imidazoles }\end{array}$ & $\begin{array}{l}\text { (Toribio et } \\
\text { al. 2014) }\end{array}$ \\
\hline
\end{tabular}

The selection of CSPs also influences the enantioseparation. Interestingly, most CSPs from HPLC applications can be adopted directly for chiral separation in SFC such as polysaccharides-based CSPs, macrocyclic antibiotic-based CSPs, Pirkle-type CSPs, and CD-based CSPs (Mangelings \& Vander Heyden 2008). For example, Thienpont et al. (1999) used amylose derivative column (Chiralpak AS) to enantioseparate ketoconazole and itraconazole and good resolution was obtained ranging from 0.8 to 2.0. In addition, studies by Del Nozal et al. (2003) and Toribio et al. $(2007,2004)$ described the separation of azoles compounds (triadimenol, triadimefon, miconazole, econazole, sulconazole, cyproconazole, propiconazole, diniconazole, hexaconazole, tetraconazole, and tebuconazole) using Chiralpak AD and good resolution (>2.0) was achieved for all compounds with the addition of organic modifiers (methanol,
$\mathrm{MeOH}$; ethanol, EtOH; and 2-propanol). Example of the electropherograms were displayed in Figures 1 and 2. Meanwhile, a comparison study was conducted on the separation performance of ketoconazole and its precursors using SFC and HPLC. It is interesting to note that ketoconazole enantiomers retained in the column of HPLC for a long time (over $60 \mathrm{~min}$ ) and gave a broader peak which hindered the resolution, while they can be separated well in SFC within 7 min with high resolution (4.29) (Bernal et al. 2002, 2000).

To sum up, although HPLC remains the most popular chromatographic technique for the enantioseparation of pharmaceutical compounds, SFC seem to be potential alternative to HPLC due to its green features such as less solvent consumption and less waste generation, apart being able to perform chiral separation at a higher flow rate with great efficacy.

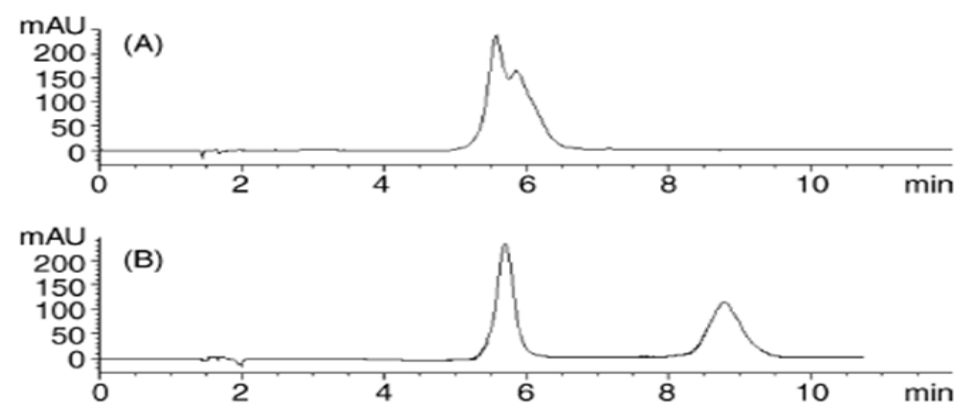

FIGURE 1. Enantiomeric separation of hexaconazole at 200 bar, $35{ }^{\circ} \mathrm{C}, 2 \mathrm{~mL} / \mathrm{min}$ and $10 \%(\mathrm{v} / \mathrm{v}) 2$-propanol. (A) Without using additives, and (B) Using $0.1 \%(\mathrm{v} / \mathrm{v})$ triethylamine and $0.1 \%(\mathrm{v} / \mathrm{v})$ trifluoroacetic acid (Toribio et al. 2004) 

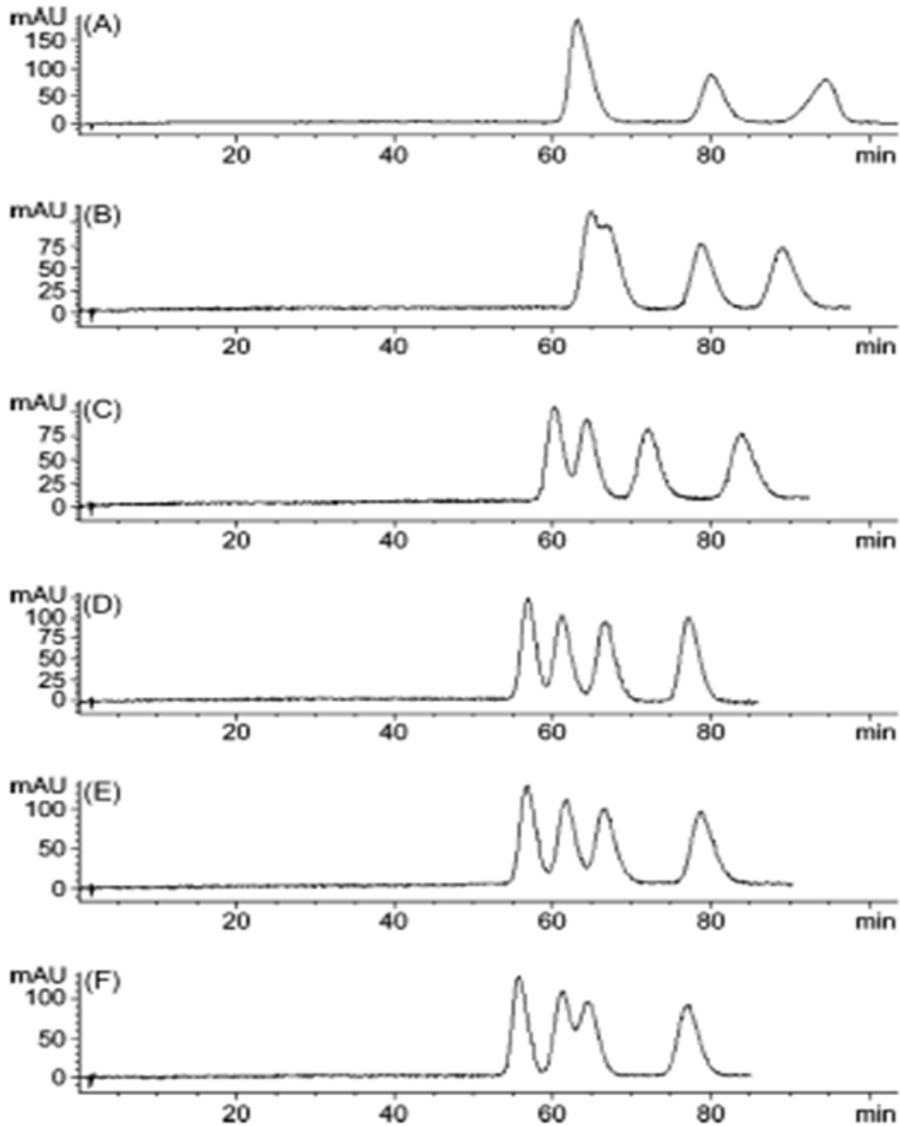

FIGURE 2. Chiral separation of itraconazole. Chromatographic conditions: 20 $\mathrm{MPa}, 2 \mathrm{~mL} / \mathrm{min}, 35^{\circ} \mathrm{C}, 40 \%$ modifier. (A) Ethanol; (B) ethanol-2-propanol, 50-50 (v/v); (C) ethanol-2-propanol, 25-75 (v/v); (D) ethanol-2-propanol, 15-85 (v/v);

(E) ethanol-2-propanol, 10-90 (v/v); (F) 2-propanol (Toribio et al. 2007)

\section{ELECTROPHORETIC METHODS}

\section{CAPILLARY ELECTROPHORESIS (CE)}

$\mathrm{CE}$ is a popular technique that has been widely explored in separation science due to their rapid analysis with minimum noise and reasonable sensitivity of detection. Besides, this technique also consumes less low solvent, chiral selector, sample volume, and is highly automated. CE also has the advantage of flexibility to change the separation media easier coupled with various separation modes such as capillary zone electrophoresis (CZE), micellar electrokinetic chromatography (MEKC), capillary gel electrophoresis, capillary isoelectric focusing (CIEF), chiral electrophoresis, and capillary electrochromatography (CEC).

However, some drawbacks of CE have been identified including inadequate injection precision, less detection sensitivity due to the short optical path length in capillary, and fluctuating in migration time during the analysis (Osbourn et al. 2000). For example, a study reported the shifting of migration time of propiconazole in diastereomer $\mathrm{B}$ that proportionate to diastereomer A from 20.6 min to 19.1 min after few months (Garrison et al. 2011). This could be due to the aging column and the use of various BGE compositions that might affected the degree of protonation at the surface of silica column.

\section{CAPILLARY ZONE ELECTROPHORESIS (CZE)}

In CZE, the background electrolytes or gels are filled in the capillary to maintain a constant electric field along the tube, in which the outcomes are translated in the form of electropherograms. The principle of separation in CZE is based on the differential migration of analytes in electric field, which results from the variances in mass-to-charge ratios. However, separation of chiral compounds in CZE is almost impossible since the enantiomers share similar mass-to-charge ratio between one another. Therefore, 
chiral selector is required in BGE solution to interact with the enantiomers to form chiral selector-analyte complex and this complex has lower electrophoretic mobility when compared to free molecules, thus allowing enantioseparation. Example of the chiral selectors are crown ethers, carbohydrates, proteins, surfactants, macro-cyclic antibiotics, bile salts, maltodextrins, ligandexchange complexes, and polysaccharides (Eeckhaut \& Michotte 2006; Gübitz \& Schmid 2008). For this, CDs are the most used chiral selector in CZE mode and known as CD-CZE (Table 3) due to its ability to encapsulate variety of compounds. The hydrophobic cavity of CDs allows the host-guest interation with hydrophobic parts of the compounds, while the hydroxyl groups located externally at the cavity can interact with the analytes using hydrogen bonding and dipole-dipole interaction.
The $\mathrm{pH}$ of BGE is also an important factor that need to be taken into consideration when developing a CZE$\mathrm{CE}$ method as it can influence the charge of enantiomers, degree of ionization of chiral selectors and also EOF. As triazole and imidazole are basic compounds with $\mathrm{pKa}$ lower than 5.0, their azole enantiomers are therefore favored in acidic medium in which they are fully ionized with positively charged and the migration is towards the cathode without the influence of electroosmotic flow. In addition, low $\mathrm{pH}$ also reduces adsorption between the cationic enantiomers and bare-fused silica surface, thus, giving opportunity for the enantiomers to interact more with the chiral selector. At the same time, low $\mathrm{pH}$ decreases the electroosmotic flow (EOF) mobility and provides adequate time for the enantiomers to complex with chiral selector, thus enhancing the resolution.

TABLE 3. CZE separation mode for chiral azole compounds

\begin{tabular}{|c|c|c|c|c|c|c|c|}
\hline $\begin{array}{c}\text { Azole } \\
\text { compound(s) }\end{array}$ & Chiral selector(s) & Type of column & Voltage $(\mathrm{kV})$ & Temp. $\left({ }^{\circ} \mathrm{C}\right)$ & $\mathrm{BGE} / \mathrm{pH}$ & Resolution & Reference \\
\hline Fenticonazole & $\begin{array}{l}\text { HP- } \beta-C D, H E-\beta- \\
\text { CD, TM- } \beta-C D \\
\text { CM- } \beta-C D\end{array}$ & $\begin{array}{l}\text { Fused-silica } \\
\text { capillary }\end{array}$ & 15.0 & 20.0 & $\begin{array}{c}\text { Phosphate BGE } \\
\text { at pH } 3.0\end{array}$ & n.s-2.1 & $\begin{array}{l}\text { (Quaglia et al. } \\
\text { 2002) }\end{array}$ \\
\hline Tioconazole & $\beta-C D$ & $\begin{array}{l}\text { Composite metals } \\
\text { column }\end{array}$ & 30 & 25 & $\begin{array}{l}\text { Phosphoric } \\
\text { acid- } \\
\text { triethanolamine } \\
\text { at pH } 3.0\end{array}$ & $>2.0$ & $\begin{array}{c}\text { (Ferguson et al. } \\
1996 \text { ) }\end{array}$ \\
\hline Econazole & $\begin{array}{c}\gamma-\mathrm{CD}, \mathrm{TM}-\gamma-\mathrm{CD} \\
\beta-\mathrm{CD}, \mathrm{HP}-\beta-\mathrm{CD} \\
\mathrm{DM}-\beta-\mathrm{CD}, \mathrm{TM}- \\
\beta-\mathrm{CD}\end{array}$ & $\begin{array}{l}\text { Fused-silica } \\
\text { capillary }\end{array}$ & $0-30$ & 32 & $\begin{array}{c}\text { Phosphate BGE } \\
\text { at pH } 2.5\end{array}$ & 2.0 & $\begin{array}{c}\text { (Dong et al. } \\
1998)\end{array}$ \\
\hline $\begin{array}{l}\text { Miconazole, } \\
\text { econazole, } \\
\text { ketoconazole, } \\
\text { itraconazole }\end{array}$ & $\begin{array}{l}\text { HP- } \beta \text {-CD with } \\
\text { different types } \\
\text { of ILs [EMIm], } \\
\mathrm{P}_{12} \mathrm{BF}_{4} \text {, DTAC }\end{array}$ & $\begin{array}{l}\text { Fused-silica } \\
\text { capillary, neutral } \\
\text { polyacrylamide } \\
\text { coated capillary }\end{array}$ & 20 & Not stated & $\begin{array}{c}\text { Phosphate BGE } \\
\text { at pH } 3.5\end{array}$ & $2.5-3.8$ & $\begin{array}{c}\text { (Zhao et al. } \\
\text { 2014) }\end{array}$ \\
\hline Enilconazole & $\begin{array}{c}\alpha-C D, H P-\alpha-C D \\
\beta-C D, D M-\beta-C D \\
\text { TM- } \beta-C D, \gamma-C D \\
\text { HP- } \gamma-C D, 2-H P- \\
\beta-C D\end{array}$ & $\begin{array}{l}\text { Fused-silica } \\
\text { capillary }\end{array}$ & 25 & 20 & $\begin{array}{c}\text { Ammonium } \\
\text { dihydrogen } \\
\text { phosphate- } \\
\text { phosphate BGE } \\
\text { at pH } 3.0\end{array}$ & n.s- 6.03 & $\begin{array}{l}\text { (Kodama et al. } \\
\text { 2003) }\end{array}$ \\
\hline $\begin{array}{l}\text { Econazole, } \\
\text { ketoconazole }\end{array}$ & $\begin{array}{c}2 \text { 2-AHP- } \beta-C D, \\
\beta-C D, D M-\beta-C D \\
\text { HP- } \beta-C D\end{array}$ & $\begin{array}{l}\text { Fused-silica } \\
\text { capillary }\end{array}$ & 20 & 25 & $\begin{array}{l}\text { Morpholinoeth- } \\
\text { anesulfonic } \\
\text { acid (MES) } \\
\text { BGE at pH 5.0 }\end{array}$ & n.s-2.11 & (Lin et al. 2004) \\
\hline $\begin{array}{l}\text { Ketoconazole and } \\
\text { other chiral drugs }\end{array}$ & $\begin{array}{c}\beta-C D, H P-\beta-C D \\
\text { HB- } \beta-C D\end{array}$ & $\begin{array}{l}\text { Fused silica } \\
\text { capillary }\end{array}$ & 15 & 25 & $\begin{array}{l}\text { Tris-phosphate } \\
\text { BGE at pH } 2.5\end{array}$ & 3.01 & (Wei et al. 2005) \\
\hline $\begin{array}{l}\text { Bifonazole, } \\
\text { econazole, } \\
\text { enilconazole, } \\
\text { ketoconazole, } \\
\text { miconazole, } \\
\text { ornidazole, } \\
\text { metomidate, } \\
\text { lofexidine }\end{array}$ & $\begin{array}{c}\alpha-\mathrm{CD}, \beta-\mathrm{CD} \\
\gamma \text {-CD, HP- } \beta-\mathrm{CD} \\
\text { SBE- } \beta-\mathrm{CD}\end{array}$ & $\begin{array}{l}\text { Fused silica } \\
\text { capillary }\end{array}$ & $\begin{array}{c}\text { Electric } \\
\text { field: } 400 \mathrm{~V} / \\
\mathrm{cm}\end{array}$ & 21 & $\begin{array}{c}\text { Phosphate BGE } \\
\text { at pH } 3.0\end{array}$ & n.s-6.75 & $\begin{array}{l}\text { (Chankvetadze } \\
\text { et al. 1995) }\end{array}$ \\
\hline
\end{tabular}

'n.s' mean no separation 


\section{ELECTROKINETIC CHROMATOGRAPHY (EKC)}

$\mathrm{EKC}$ is another separation mode in $\mathrm{CE}$ that separates ionic and non-ionic analytes. This mode was initiated by Terabe et al. (1984) to separate phenolic compounds in which the authors highlighted the use of electrokinetic separation, micellar solution, and surfactant to improve the resolution and to widen the applications towards water-insoluble compounds. In comparison to CZE, the ionic pseudostationary phase that possesses its own electrophoretic mobility is being added into the normal BGE and two phases are formed. Thereafter, the analytes will distribute themselves between the two phases. Example of pseudostationary phases include surfactants, microemulsions, micelles, macrocyclic, and macromolecular. These EKC methods and pseudostationary phases are further described in several review works (Nishi 1996; Quirino \& Terabe 1999).

The term 'micellar' is used for EKC mode because of the amphiphilic molecules, such as surfactant which tends to form micelles upon the critical micelle concentration (CMC). Different types of surfactants used in MEKC have been discussed by Nishi and Terabe (1996). In this mode, the enantiomers will distribute themselves between the electrolyte bulk phase and the chiral micelle phase. The micelle phase then will complex with the neutral analytes before being migrated to the cathode under the influence of electroosmotic flow. A chiral selector is added to selectively complex the enantiomers of the chiral analyte, creating diastereomers that, in turn, complex with the micelle to various degrees and allow separation by the system. Nevertheless, there are some factors that can lead to poor resolution in using MEKC mode. For example, this mode is not suitable for hydrophobic analytes as they will strongly associate with SDS micelles (Alagar et al. 2014), thus minimizing the chance for the enantiomers to interact with the chiral selector.

Besides surfactants, the application of CDs in EKC has also received great attention among researchers because they do not only act as pseudostationary phases such as micelles, but also as chiral-discriminating agents, hence allowing the separation of both neutral and charged analytes. Since the pKa values of most azole compounds are similar $(\mathrm{pKa}=\sim 5.0)$, their structure turns to play important role to form various interactions, such as hydrogen bonding, electrostatic force, steric effects, and impact on hydrophobicity. This factor is crucial to promote the interaction of enantiomers with derivatized CDs and discriminate among each other, as reported by $\mathrm{Wu}$ et al. (2001), who have successfully separated fourteen triazole fungicides using sulfated$\beta-C D$ and the electropherogram was illustrated in Figure 3. In addition, Wan Ibrahim et al. (2009a) also had extensively studied the enantioseparation of chiral azole compounds with various types of CDs, such as hydroxypropyl- $\gamma$-CD (HP- $\gamma$-CD) for econazole (Hermawan et al. 2010), hexaconazole, penconazole, myclobutanil, $\gamma$-CD, hydroxypropyl- $\beta-\mathrm{CD}$ (HP- $\beta-\mathrm{CD})$ for cyproconazole, bromuconazole, and diniconazole (Wan Ibrahim et al. $2009 b)$. Neutral heptakis(2,6-di-o-methyl)- $\beta$-CD (DM$\beta$-CD) was also employed to separate tioconazole, isoconazole, and fenticonazole (Wan Ibrahim et al. 2013). Whereas, TM- $\beta$-CD was used to investigate the chiral recognition of ketoconazole enantiomers (Wan Ibrahim et al. 2014). Therefore, it can be concluded that derivatized CDs are widely applied in CE when compared to other macromolecules, as portrayed in Table 4.

TABLE 4. EKC separation mode for chiral azole compounds

\begin{tabular}{|c|c|c|c|c|c|c|c|c|}
\hline $\begin{array}{l}\text { Mode of } \\
\text { EKC }\end{array}$ & Analyte (s) & $\begin{array}{l}\text { Chiral } \\
\text { selectors }\end{array}$ & $\begin{array}{l}\text { Type of } \\
\text { column }\end{array}$ & $\begin{array}{l}\text { Voltage } \\
(\mathrm{kV})\end{array}$ & $\begin{array}{l}\text { Temp. } \\
\left({ }^{\circ} \mathrm{C}\right)\end{array}$ & $\begin{array}{l}\text { Micellar solution/ } \\
\text { surfactant in BGE } \\
\& \mathrm{pH}\end{array}$ & Resolution & Reference \\
\hline CD-MEKC & Econazole & $\mathrm{HP}-\gamma-\mathrm{CD}$ & $\begin{array}{l}\text { Fused silica } \\
\text { capillary }\end{array}$ & 30 & 25 & $\begin{array}{l}20 \mathrm{mM} \text { of phosphate } \\
\mathrm{BGE} \text { and } 50 \mathrm{mM} \text { of } \\
\text { SDS at } \mathrm{pH} 8\end{array}$ & $>2.0$ & $\begin{array}{c}\text { (Hermawan et al. } \\
\text { 2010) }\end{array}$ \\
\hline CD-MEKC & $\begin{array}{l}\text { Tioconazole, } \\
\text { isoconazole, } \\
\text { fentionazole }\end{array}$ & $\begin{array}{l}\mathrm{HP}-\beta-C D \\
\mathrm{HP}-\gamma-\mathrm{CD}, \\
\mathrm{DM}-\beta-\mathrm{CD}\end{array}$ & $\begin{array}{l}\text { Fused-silica } \\
\text { capillary }\end{array}$ & 27 & 30 & $\begin{array}{c}35 \mathrm{mM} \text { of phosphate } \\
\text { BGE, } 50 \mathrm{mM} \text { SDS, } \\
\text { and } 15 \%(\mathrm{v} / \mathrm{v}) \mathrm{ACN} \\
\text { at } \mathrm{pH} 7.0\end{array}$ & $1.90-7.22$ & $\begin{array}{c}\text { (Wan Ibrahim et } \\
\text { al. 2013) }\end{array}$ \\
\hline CD-MEKC & $\begin{array}{l}\text { Hexaconazole, } \\
\text { penconazole, } \\
\text { myclobutanil }\end{array}$ & $\mathrm{HP}-\gamma-\mathrm{CD}$ & $\begin{array}{l}\text { Fused-silica } \\
\text { capillary }\end{array}$ & -25 & 25 & $\begin{array}{c}25 \mathrm{mM} \text { phosphate } \\
\text { BGE and } 50 \mathrm{mM} \\
\text { SDS at } \mathrm{pH} 3.0\end{array}$ & $>1.60$ & $\begin{array}{c}\text { (Wan Ibrahim et } \\
\text { al. 2009a) }\end{array}$ \\
\hline CD-MEKC & $\begin{array}{l}\text { Cyproconazole, } \\
\text { bromuconazole, } \\
\text { diniconazole }\end{array}$ & $\begin{array}{l}\mathrm{HP}-\beta-C D \\
\mathrm{HP}-\gamma-\mathrm{CD}\end{array}$ & $\begin{array}{c}\text { Fused silica } \\
\text { capillary }\end{array}$ & 25 & 20 & $\begin{array}{l}25 \mathrm{mM} \text { phosphate } \\
\text { BGE, MeOH: ACN } \\
10 \%: 5 \mathrm{v} / \mathrm{v} \text {, and } 40 \\
\mathrm{mM} \text { SDS at pH } 3.0\end{array}$ & $1.1-15.9$ & $\begin{array}{c}\text { (Wan Ibrahim et } \\
\text { al. 2009b) }\end{array}$ \\
\hline CD-MEKC & $\begin{array}{l}\text { Hexaconazole, } \\
\text { penconazole, } \\
\text { myclobutanil }\end{array}$ & $\mathrm{HP}-\gamma-\mathrm{CD}$ & $\begin{array}{l}\text { Fused silica } \\
\text { capillary }\end{array}$ & -25 & 35 & $\begin{array}{c}25 \mathrm{mM} \text { phosphate } \\
\text { BGE and } 50 \mathrm{mM} \\
\text { SDS at } \mathrm{pH} 3.0\end{array}$ & $>1.60$ & $\begin{array}{c}\text { (Wan Ibrahim et } \\
\text { al. 2010) }\end{array}$ \\
\hline
\end{tabular}




\begin{tabular}{|c|c|c|c|c|c|c|c|c|}
\hline $\begin{array}{l}\text { CD- } \\
\text { MEKC }\end{array}$ & Ketoconazole & TM- $\beta-C D$ & $\begin{array}{c}\text { Fused silica } \\
\text { capillary }\end{array}$ & 25 & 25 & $\begin{array}{c}10 \mathrm{mM} \text { phosphate } \\
\text { BGE, } 5 \mathrm{mM} \text { SDS, } \\
\text { and } 1.0 \%(\mathrm{v} / \mathrm{v}) \\
\text { methanol }\end{array}$ & $>1.5$ & $\begin{array}{c}\text { (Wan Ibrahim et } \\
\text { al. 2015) }\end{array}$ \\
\hline CD-EKC & $\begin{array}{l}\text { Ketoconazole, } \\
\text { terconazole }\end{array}$ & TM- $\beta-C D$ & $\begin{array}{l}\text { Fused-silica } \\
\text { capillary }\end{array}$ & 30 & 15 & $\begin{array}{c}\text { Phosphate BGE at } \\
\text { pH } 3.5\end{array}$ & $>2.0$ & $\begin{array}{c}\text { (Castro-Puyana } \\
\text { et al. 2005) }\end{array}$ \\
\hline CD-EKC & Itraconazole & TM- $\beta-C D$ & $\begin{array}{c}\text { Fused-silica } \\
\text { capillary }\end{array}$ & 30 & 20 & $\begin{array}{c}\text { Phosphate BGE at } \\
\text { pH } 2.5\end{array}$ & $>3.0$ & $\begin{array}{c}\text { (Castro-Puyana } \\
\text { et al. 2006) }\end{array}$ \\
\hline CD-EKC & $\begin{array}{l}\text { Miconazole, } \\
\text { econazole, } \\
\text { sulconazole, } \\
\text { bifonazole, } \\
\text { terconazole, } \\
\text { ketoconazole }\end{array}$ & $\begin{array}{l}\mathrm{HP}-\beta-C D \\
\text { TM- } \beta-C D\end{array}$ & $\begin{array}{c}\text { Fused-silica } \\
\text { capillary }\end{array}$ & 30 & 15 & $\begin{array}{c}\text { Phosphate BGE at } \\
\text { pH } 3.0\end{array}$ & $1.2-5.2$ & $\begin{array}{c}\text { (Castro-Puyana } \\
\text { et al. 2007) }\end{array}$ \\
\hline CD-EKC & $\begin{array}{c}\text { bitertanol, } \\
\text { cyproconazole, } \\
\text { difenoconazole, } \\
\text { diniconazole, } \\
\text { flutriafol, } \\
\text { hexaconazole, } \\
\text { myclobutanil, } \\
\text { paclobutrazol, } \\
\text { penconazole, } \\
\text { propiconazole, } \\
\text { tebuconazole, } \\
\text { tetraconazole, } \\
\text { triadimefon and } \\
\text { triadimenol. }\end{array}$ & $\begin{array}{l}\text { Sulfated- } \beta- \\
\quad \text { CD }\end{array}$ & $\begin{array}{c}\text { Fused-silica } \\
\text { capillary }\end{array}$ & -18 & N/A & $\begin{array}{c}\text { Phosphate BGE with } \\
2 \% \text { sulfated- } \beta-C D \text { at } \\
\text { pH } 3.0\end{array}$ & N.A & (Wu et al. 2001) \\
\hline
\end{tabular}

N.A means not available

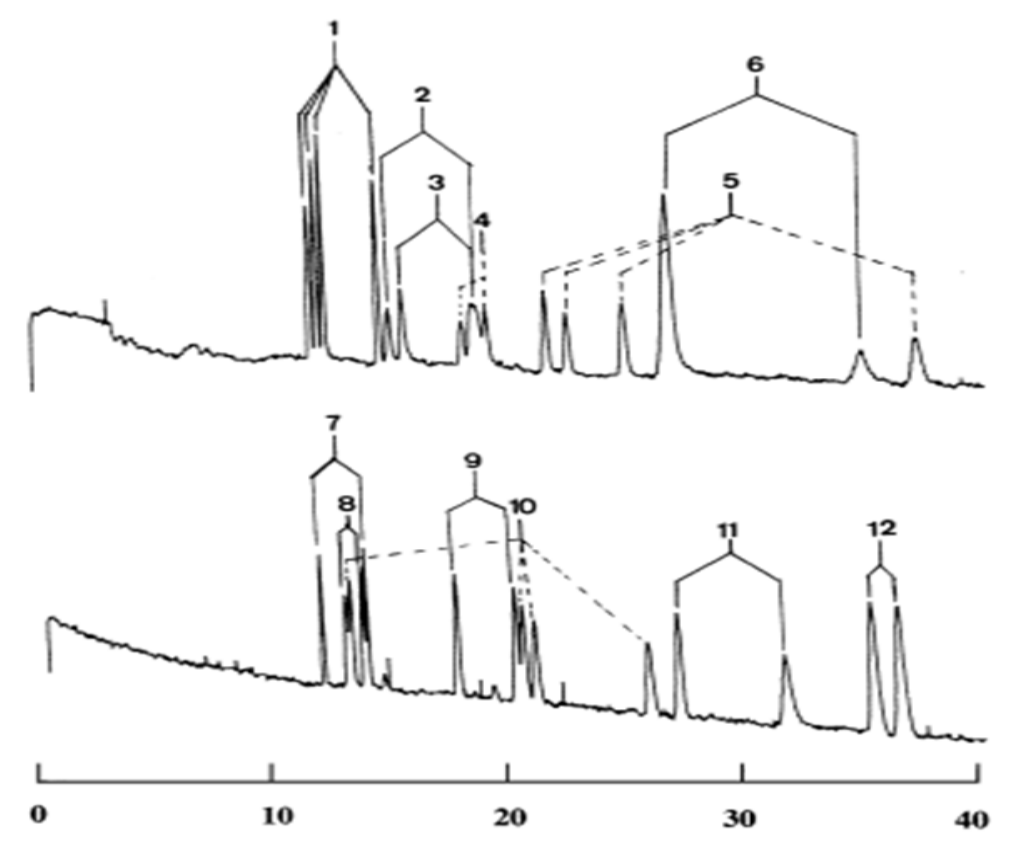

FIGURE 3. Chiral separation of twelve triazole fungicides by S- $\beta$-CD mediated CE. Running electrolyte, phosphate buffer with $2 \% \mathrm{~S}-\beta-\mathrm{CD}, \mathrm{pH} 3.0$. High voltage, $-18 \mathrm{kV}$. Capillary, $60 \mathrm{~cm} \mathrm{(53}$ $\mathrm{cm}$ effective length) $\times 50 \mu . \mathrm{m}$ I.D.; UV detection, $220 \mathrm{~nm}$. Peak identification: 1, cyproconazole;

2, penconazole; 3 , hexaconazole; 4 , tetraconazole; 5 , triadimenol; 6 , diniconazole $(9: 1 \mathrm{R}: \mathrm{S}$ mixture); 7, paclobutrazol (dominated by 2RS, 3RS isomers); 8 , tebuconazole; 9 , flutriafol; 10 , propiconazole; 11, triadimefon and 12, myclobutanil (Wu et al. 2001) 


\section{CONClusion AND Future Perspective}

This review has successfully presented the past studies on the chiral separation of azole compounds using chromatographic (HPLC, GC, and SFC) and electrophoretic (CE) techniques. It is noticeably that HPLC coupled with UV detection seems to be favorable technique among the researchers as it is able to separate a large number of chiral compounds, including thermally labile and high molecular weight compounds which cannot be resolved by using GC technique. Moreover, variety of CSPs have also been developed in order to achieve good chiral separation of the azole compounds. Next, CE techniques have also gradually received attention in chiral analysis as they offer wide range of separation modes and beneficial advantages over the other techniques. Nonetheless, they suffer from limited sensitivity due to the short optical path length in capillary detection. Apart from that, the role of chiral selectors, CSPs, additives and modifiers in the chiral analysis of azole compounds are also described.

For future perspective, it has been noted that the application of reported chiral separation methods for real samples are limited. Therefore, more applications should be carried out on real samples such as in pharmaceutical products, biological samples, as well as environmental samples. Besides that, the commercial CSPs that commonly used are polysaccharides-based, however, the cyclodextrin-based CPSs are still scarcely explored. Thus, further investigation on the use of CD-based CSPs for enantioseparation of azole compounds are required. Lastly, the application of ultra- performance HPLC (UHPLC) and SFC in chiral separation of azole compounds can also be expanded as they are able to provide shorter analysis time while maintaining the separation efficiency.

\section{ACKNOWLEDGEMENTS}

This work was supported by the Fundamental Research Grant Scheme from the Ministry of Higher Education (MOHE), Malaysia (FRGS, 203/CIPPT/6711557) and University Malaya Faculty Research Grant, (GPF058B-2018). The authors declare no conflict of interest.

\section{REFERENCES}

Aboul-Enein, H.Y. \& Ali, I. 2004. Applications of polysaccharidebased chiral stationary phases for resolution of different compound classes. In Chiral Separations: Methods in Molecular Biology, edited by Gübitz, G. \& Schmid, M.G. New Jersey: Humana Press. vol. 243. pp. 183-196.

Aboul-Enein, H.Y. \& Ali, I. 2002. Comparative study of the enantiomeric resolution of chiral antifungal drugs econazole, miconazole and sulconazole by HPLC on various cellulose chiral columns in normal phase mode. Journal of Pharmaceutical and Biomedical Analysis 27(3-4): 441-446.

Aboul-Enein, H.Y. \& Ali, I. 2001. Comparison of the chiral resolution of econazole, miconazole, and sulconazole by
HPLC using normal-phase amylose CSPs. Fresenius 'Journal of Analytical Chemistry 370(7): 951-955.

Aboul-Enein, H.Y. \& Bakr, S.A. 1998. Enantiomeric resolution of propranolol and analogs on two cellulose (Chiralcel OF and OC) and one amylose (Chiralpak AD) chiral stationary phases. Journal of Liquid Chromatography \& Related Technologies 21(8): 1137-1145.

Alagar, R.M., Bhargav, K.S., Banji, D. \& Selva, K.D. 2014. Updated review on micellar electro kinetic chromatography. Journal of Chromatography and Separation Techniques 5: 1-6.

Ali, I., Aboul-Enein, H.Y., Gaitonde, V.D., Singh, P., Rawat, M.S.M. \& Sharma, B. 2009. Chiral separations of imidazole antifungal drugs on amycoat RP column in HPLC. Chromatographia 70(1-2): 223-227.

Andrade, R.T., da Silva, R.C.S., Pereira, A.C. \& Borges, K.B. 2015. Self-assembly pipette tip-based cigarette filters for micro-solid phase extraction of ketoconazole cis-enantiomers in urine samples followed by high-performance liquid chromatography/diode array detection. Analytical Methods 7(17): 7270-7279.

Anwar-Mohamed, A., El-Sherbeni, A.A., Hamdy, D.A., Korashy, H.M., Brocks, D.R. \& El-Kadi, A. O. 2016. Ketoconazole stereoisomers differentially induce cytochrome P450 1A1 between human hepatoma HepG2 and mouse hepatoma Hepa1c1c7 cells. Journal of Pharmaceutical Sciences 105: 1318-1326.

Aperis, G. \& Mylonakis, E. 2006. Newer triazole antifungal agents: Pharmacology, spectrum, clinical efficacy and limitations. Expert Opinion on Investigational Drugs 15(6): 579-602.

Armstrong, D.W. 1984. Chiral stationary phases for high performance liquid chromatographic separation of enantiomers: A mini-review. Journal of Liquid Chromatography 7(S2): 353-376.

Benfield, P. \& Stephen, P. 1988. Sulconazole. Drugs 35(2): 143-153.

Bernal, J.L., Toribio, L., Del Nozal, M.J., Nieto, E.M. \& Montequi, M.I. 2002. Separation of antifungal chiral drugs by SFC and HPLC: A comparative study. Journal of Biochemical and Biophysical Methods 54(1-3): 245-254.

Bernal, J.L., Del Nozal, M.J., Toribio, L., Montequi, M.I. \& Nieto, E.M. 2000. Separation of ketoconazole enantiomers by chiral subcritical-fluid cromatography. Journal of Biochemical and Biophysical Methods 43(1-3): 241-250.

Bhanderi, B.B., Yadav, M.M. \& Roy, A. 2009. Antifungal drug resistance - concerns for veterinarians. Veterinary World 2(5): 204-207.

Bi, C., Zhao, E., Liu, Y., Qiu, J. \& Zhou, Z. 2006. Direct optical resolution of chiral pesticides by HPLC on emamectin CSP under normal phase conditions. Journal of Liquid Chromatography and Related Technologies 29(11): 16011607.

Bicchi, C., Cravotto, G., D'amato, A., Rubiolo, P., Galli, A. \& Galli, M. 1999. Cyclodextrin derivatives in gas chromatographic separation of racemates with different volatility. part XV: 6-o-t-Butyldimethylsilyl-versus 6-o-tHexyldimethylsilyl- $\beta$ and $-\gamma$ Derivatives. Journal of Microcolumn Separations 11(7): 487-500. 
Bounoua, N., Sekkoum, K., Belboukhari, N., Cheriti, A. \& Aboul-Enein, H.Y. 2016. Achiral and chiral separation and analysis of antifungal drugs by HPLC and CE: A comparative study: Mini review. Journal of Liquid Chromatography \& Related Technologies 39(11): 513-519.

Brauer, V.S., Rezende, C.P., Pessoni, A.M., De Paula, R.G., Rangappa, K.S., Nayaka, S.C., Gupta, V.K. \& Almeida, F. 2019. Antifungal agents in agriculture: Friends and foes of public health. Biomolecules 9(10): 521.

Burden, R.S., Deas, A.H. \& Clark, T. 1987. Separation of enantiomers of fungicidal and plant growth regulatory triazole alcohols using chiral derivatisation and capillary gas chromatography. Journal of Chromatography A 391: 273-279.

Cai, X.J., Xu, X.Z. \& Pan, C.X. 2005. Study of optical isomer separation of chiral antifungal drugs tetramisole, miconazole, and paclobutrazol on two chiral stationary phases. Analytical Letters 38(7): 1149-1157.

Castro-Puyana, M., Crego, A.L., Marina, M.L. \& García-Ruiz, C. 2007. Enantioselective separation of azole compounds by EKC. Reversal of migration order of enantiomers with CD concentration. Electrophoresis 28(15): 2667-2674.

Castro-Puyana, M., Crego, A.L. \& Marina, M.L. 2006. Separation and quantitation of the four stereoisomers of itraconazole in pharmaceutical formulations by electrokinetic chromatography. Electrophoresis 27(4): 887-895.

Castro-Puyana, M., Crego, A.L. \& Marina, M.L. 2005. Enantiomeric separation of ketoconazole and terconazole antifungals by electrokinetic chromatography: Rapid quantitative analysis of ketoconazole in pharmaceutical formulations. Electrophoresis 26(20): 3960-3968.

Chankvetadze, B., Endresz, G. \& Blaschke, G. 1995. Enantiomeric resolution of chiral imidazole derivatives using capillary electrophoresis with cyclodextrin-type buffer modifiers. Journal of Chromatography A 700(1-2): 43-49.

Cheng, Y., Dong, F., Liu, X., Xu, J., Li, J., Chen, X., Li, Y., Wu, X. \& Zheng, Y., 2013. Stereoselective separation and determination of the triazole fungicide propiconazole in water, soil and grape by normal phase HPLC. Analytical Methods 5(3): 755-761.

Cirilli, R., Costi, R., Di Santo, R., Ferretti, R., La Torre, F., Angiolella, L. \& Micocci, M. 2002. Analytical and semipreparative enantiomeric separation of azole antifungal agents by high-performance liquid chromatography on polysaccharide-based chiral stationary phases: Application to in vitro biological studies. Journal of Chromatography $A$ 942(1-2): 107-114.

Como, J.A. \& Dismukes, W.E. 1994. Oral azole drugs as systemic antifungal therapy. New England Journal of Medicine 330(4): 263-272.

Crego, A.L., Marina, M.L. \& Lavandera, J.L. 2001. Optimization of the separation of a group of antifungals by capillary zone electrophoresis. Journal of Chromatography A 917(1-2): 337-345.

Del Nozal, M.J., Toribio, L., Bernal, J.L. \& Castano, N. 2003. Separation of triadimefon and triadimenol enantiomers and diastereoisomers by supercritical fluid chromatography. Journal of Chromatography A 986(1): 135-141.

Dilmaghanian, S., Gerber, J.G., Filler, S.G., Sanchez, A. \& Gal, J. 2004. Enantioselectivity of inhibition of cytochrome
P450 3A4 (CYP3A4) by ketoconazole: Testosterone and methadone as substrates. Chirality: The Pharmacological, Biological, and Chemical Consequences of Molecular Asymmetry 16(2): 79-85.

Dong, F., Li, J., Chankvetadze, B., Cheng, Y., Xu, J., Liu, X., Li, Y., Chen, X., Bertucci, C., Tedesco, D. \& Zanasi, R. 2013. Chiral triazole fungicide difenoconazole: Absolute stereochemistry, stereoselective bioactivity, aquatic toxicity, and environmental behavior in vegetables and soil. Environmental Science \& Technology 47(7): 3386-3394.

Dong, Y., Ren, X., Huang, A., Sun, Y. \& Sun, Z. 1998. Chiral separation of bencynonate and econazole by cyclodextrinmodified capillary zone electrophoresis. HRC. Journal of High Resolution Chromatography 21(7): 421-423.

Eeckhaut, A. \& Michotte, Y. 2006. Chiral separations by capillary electrophoresis: Recent developments and applications. Electrophoresis 27(14): 2880-2895.

Ferguson, P.D., Goodall, D.M. \& Loran, J.S. 1996. Systematic approach to the treatment of enantiomeric separations in capillary electrophoresis and liquid chromatography III. A binding constant-retention factor relationship and effects of acetonitrile on the chiral separation of tioconazole. Journal of Chromatography A 745(1-2): 25-35.

Gala, D., DiBenedetto, D.J., Mergelsberg, I., Kugelman, M. \& Research, S.P. 1996. Total chiral synthesis of azole antifungals via $\alpha$-hydroxylation of ketones. Tetrahedron Letters 37(45): 8117-8120.

Garrison, A.W., Avants, J.K. \& Miller, R.D. 2011. Loss of propiconazole and its four stereoisomers from the water phase of two soil-water slurries as measured by capillary electrophoresis. International Journal of Environmental Research and Public Health 8(8): 3453-3467.

Ghanem, A., Hoenen, H. \& Aboul-Enein, H.Y. 2006. Application and comparison of immobilized and coated amylose tris-(3, 5-dimethylphenylcarbamate) chiral stationary phases for the enantioselective separation of $\beta$-blockers enantiomers by liquid chromatography. Talanta 68(3): 602-609.

Ghannoum, M.A. \& Rice, L.B. 1999. Antifungal agents: Mode of action, mechanisms of resistance, and correlation of these mechanisms with bacterial resistance. Clinical Microbiology Reviews 12(4): 501-517.

Girmenia, C. 2009. New generation azole antifungals in clinical investigation. Expert Opinion on Investigational Drugs 18(9): 1279-1295.

Gübitz, G. 1990. Separation of drug enantiomers by HPLC using chiral stationary phases - A selective review. Chromatographia 30(9-10): 555-564.

Gübitz, G. \& Schmid, M.G. 2008. Chiral separation by capillary electromigration techniques. Journal of Chromatography A 1204(2): 140-156.

Hamdy, D.A. \& Brocks, D.R. 2008. A stereospecific highperformance liquid chromatographic assay for the determination of ketoconazole enantiomers in rat plasma. Biomedical Chromatography 22(5): 542-547.

Hermawan, D., Ibrahim, W.A.W., Sanagi, M.M. \& Aboul-Enein, H.Y. 2010. Chiral separation of econazole using micellar electrokinetic chromatography with hydroxypropyl- $\gamma$ cyclodextrin. Journal of Pharmaceutical and Biomedical Analysis 53(5): 1244-1249. 
Hiroyuki, N. \& Terabe, S. 1996. Micellar electrokinetic chromatography perspectives in drug analysis. Journal of Chromatography A 735(1-2): 3-27.

Huang, Q., Zhang, K., Wang, Z., Wang, C. \& Peng, X. 2012. Enantiomeric determination of azole antifungals in wastewater and sludge by liquid chromatography-tandem mass spectrometry. Analytical and Bioanalytical Chemistry 403(6): 1751-1760.

Ilisz, I., Berkecz, R. \& Péter, A. 2008. Application of chiral derivatizing agents in the high-performance liquid chromatographic separation of amino acid enantiomers: A review. Journal of Pharmaceutical and Biomedical Analysis 47(1): 1-15.

Ilisz, I., Berkecz, R. \& Péter, A. 2006. HPLC separation of amino acid enantiomers and small peptides on macrocyclic antibiotic-based chiral stationary phases: A review. Journal of Separation Science 29(10): 1305-1321.

Kim, H., Radwanski, E., Lovey, R., Lin, C.C. \& Nomeir, A.A. 2002. Pharmacokinetics of the active antifungal enantiomer, SCH 42427 (RR), and evaluation of its chiral inversion in animals following its oral administration and the oral administration of its racemate genaconazole (RR/SS). Chirality: The Pharmacological, Biological, and Chemical Consequences of Molecular Asymmetry 14(5): 436-441.

Kodama, S., Yamamoto, A., Ohura, T., Matsunaga, A. \& Kanbe, T. 2003. Enantioseparation of imazalil residue in orange by capillary electrophoresis with 2-hydroxypropyl- $\beta$ cyclodextrin as a chiral selector. Journal of Agricultural and Food Chemistry 51(21): 6128-6131.

Lämmerhofer, M. 2010. Chiral recognition by enantioselective liquid chromatography: Mechanisms and modern chiral stationary phases. Journal of Chromatography A 1217(6): 814-856.

Li, J., Dong, F., Xu, J., Liu, X., Li, Y., Shan, W. \& Zheng, Y. 2011. Enantioselective determination of triazole fungicide simeconazole in vegetables, fruits, and cereals using modified QuEChERS (quick, easy, cheap, effective, rugged and safe) coupled to gas chromatography/tandem mass spectrometry. Analytica Chimica Acta 702(1): 127-135.

Li, Y., Dong, F., Liu, X., Xu, J., Li, J., Kong, Z., Chen, X., Liang, X. \& Zheng, Y. 2012. Simultaneous enantioselective determination of triazole fungicides in soil and water by chiral liquid chromatography/tandem mass spectrometry. Journal of Chromatography A 1224: 51-60.

Lin, X., Zhu, C. \& Hao, A. 2004. Evaluation of newly synthesized derivative of cyclodextrin for the capillary electrophoretic separation. Journal of Chromatography A 1059(1-2): 181189.

Lv, C. \& Zhou, Z. 2011. Chiral HPLC separation and absolute configuration assignment of a series of new triazole compounds. Journal of Separation Science 34(4): 363-370.

Maertens, J.A. 2004. History of the development of azole derivatives. Clinical Microbiology and Infection 10: 1-10.

Mangelings, D. \& Vander Heyden, Y. 2008. Chiral separations in sub-and supercritical fluid chromatography. Journal of Separation Science 31(8): 1252-1273.

Mskhiladze, A., Karchkhadze, M., Dadianidze, A., Fanali, S., Farkas, T. \& Chankvetadze, B. 2013. Enantioseparation of chiral antimycotic drugs by HPLC with polysaccharide- based chiral columns and polar organic mobile phases with emphasis on enantiomer elution order. Chromatographia 76(21-22): 1449-1458.

Nagarjuna, A., Reddy, K.P., Mukkanti, K. \& Suryanarayana, M.V. 2007. A validated LC method for separation and quantification of voriconazole and its enantiomer. Chromatographia 66(5-6): 439-441.

Nishi, H. 1996. Enantiomer separation of drugs by electrokinetic chromatography. Journal of Chromatography A 735(1-2): 57-76.

Nishi, H. \& Terabe, S. 1995. Optical resolution of drugs by capillary electrophoretic techniques. Journal of Chromatography A 694(1) 245-276.

Okamoto, Y. \& Kaida, Y. 1994. Resolution by high-performance liquid chromatography using polysaccharide carbamates and benzoates as chiral stationary phases. Journal of Chromatography A 666(1-2): 403-419.

Osbourn, D.M., Weiss, D.J. \& Lunte, C.E. 2000. On-line preconcentration methods for capillary electrophoresis. ELECTROPHORESIS: An International Journal 21(14): 2768-2779.

Otsuka, K. \& Terabe, S. 2000. Enantiomer separation of drugs by micellar electrokinetic chromatography using chiral surfactants. Journal of Chromatography A 875(1-2): 163-178.

Pan, C.X., Shen, B.C., Xu, B.J., Chen, J.J. \& Xu, X.Z. 2006. Comparative enantioseparation of seven triazole fungicides on (S, S)-Whelk O1 and four different cellulose derivative columns. Journal of Separation Science 29(13): 2004-2011.

Pérez-Fernández, V., García, M.Á. \& Marina, M.L. 2011. Chiral separation of agricultural fungicides. Journal of Chromatography A 1218(38): 6561-6582.

Quaglia, M.G., Donati, E., Desideri, N., Fanali, S., D'auria, F.D. \& Tecca, M. 2002. Chiral discrimination by HPLC and $\mathrm{CE}$ and antifungal activity of racemic fenticonazole and its enantiomers. Chirality: The Pharmacological, Biological, and Chemical Consequences of Molecular Asymmetry 14(5): 449-454.

Quirino, J.P. \& Terabe, S. 1999. Electrokinetic chromatography. Journal of Chromatography A 856(1-2): 465-482.

Saito, K., Yato, M., Ito, T., Iwasaki, Y., Ito, R., Matsuki, Y. \& Nakazawa, H. 2008. Verification of the need for optical purity measurement of chiral pesticide standards as agricultural reference materials. Accreditation and Quality Assurance 13(7): 373-379.

Scorzoni, L., de Paula e Silva, A.C., Marcos, C.M., Assato, P.A., de Melo, W.C., de Oliveira, H.C., Costa-Orlandi, C.B., Mendes-Giannini, M.J. \& Fusco-Almeida, A.M. 2017. Antifungal therapy: New advances in the understanding and treatment of mycosis. Frontiers in Microbiology 8: 36.

Sellergren, B. 2001. Imprinted chiral stationary phases in high-performance liquid chromatography. Journal of Chromatography A 906(1-2): 227-252.

Shalini, K., Kumar, N., Drabu, S. \& Sharma, P.K. 2011. Advances in synthetic approach to and antifungal activity of triazoles. Beilstein Journal of Organic Chemistry 7(1): 668-677.

Suedee, R., Saelim, J., Thavornpibulbut, T. \& Srichana, T. 1999. Chiral determination of various adrenergic drugs by thinlayer chromatography using molecularly imprinted chiral stationary phases prepared with $\alpha$-agonists. Analyst 124(7): 1003-1009. 
Tachibana, K. \& Ohnishi, A. 2001. Reversed-phase liquid chromatographic separation of enantiomers on polysaccharide type chiral stationary phases. Journal of Chromatography A 906(1-2): 127-154.

Terabe, S., Otsuka, K., Ichikawa, K., Tsuchiya, A. \& Ando, T. 1984. Electrokinetic separations with micellar solutions and open-tubular capillaries. Analytical Chemistry 56(1): 111-113.

Thienpont, A., Gal, J., Aeschlimann, C. \& Felix, G. 1999. Studies on stereoselective separations of the" azole" antifungal drugs ketoconazole and itraconazole using HPLC and SFC on silica-based polysaccharides. Analusis 27(8): 713-718.

Toribio, L., Bernal, J.L., Martín, M.T., Bernal, J. \& Del Nozal, M.J. 2014. Effects of organic modifier and temperature on the enantiomeric separation of several azole drugs using supercritical fluid chromatography and the Chiralpak AD column. Biomedical Chromatography 28(1) 152-158.

Toribio, L., del Nozal, M.J., Bernal, J.L., Alonso, C. \& Jiménez, J.J. 2007. Enantiomeric separation of several antimycotic azole drugs using supercritical fluid chromatography. Journal of Chromatography A 1144(2): 255-261.

Toribio, L., Del Nozal, M.J., Bernal, J.L., Jiménez, J.J. \& Alonso, C. 2004. Chiral separation of some triazole pesticides by supercritical fluid chromatography. Journal of Chromatography A 1046(1-2): 249-253.

Wan Ibrahim, W.A., Arsad, S.R., Maarof, H., Sanagi, M.M. \& Aboul-Enein, H.Y. 2015. Chiral separation of four stereoisomers of ketoconazole drugs using capillary electrophoresis. Chirality 27(3): 223-227.

Wan Ibrahim, W.A., Arsad, S.R., Maarof, H. \& Sanagi, M.M. 2014. Experimental and theoretical study on chiral recognition mechanism of ketoconazole enantiomers using heptakis (2, 3, 6-tri-O-methyl)- $\beta$-cyclodextrin. Malaysian Journal of Fundamental and Applied Sciences 10: 2.

Wan Ibrahim, W.A., Abd Wahib, S.M., Hermawan, D., Sanagi, M.M. \& Aboul-Enein, H.Y. 2013. Separation of selected imidazole enantiomers using dual cyclodextrin system in micellar electrokinetic chromatography. Chirality 25(6): 328-335.

Wan Ibrahim, W.A., Hermawan, D., Sanagi, M.M. \& AboulEnein, H.Y. 2010. Stacking and sweeping in cyclodextrinmodified MEKC for chiral separation of hexaconazole, penconazole and myclobutanil. Chromatographia 71(3-4): 305-309.

Wan Ibrahim, W.A., Hermawan, D., Sanagi, M.M. \& AboulEnein, H.Y. 2009a. Cyclodextrin-modified MEKC for enantioseparation of hexaconazole, penconazole, and myclobutanil. Journal of Separation Science 32(3): 466-471.

Wan Ibrahim, W.A., Warno, S.A., Aboul-Enein, H.Y., Hermawan, D. \& Sanagi, M.M. 2009b. Simultaneous enantioseparation of cyproconazole, bromuconazole, and diniconazole enantiomers by CD-modified MEKC. Electrophoresis 30(11): 1976-1982.

Wang, P., Liu, D., Jiang, S., Xu, Y. \& Zhou, Z. 2008. The chiral separation of triazole pesticides enantiomers by amylosetris (3, 5-dimethylphenylcarbamate) chiral stationary phase. Journal of Chromatographic Science 46(9): 787-792.

Wang, P., Jiang, S., Liu, D., Wang, P. \& Zhou, Z. 2005. Direct enantiomeric resolutions of chiral triazole pesticides by high-performance liquid chromatography. Journal of
Biochemical and Biophysical Methods 62(3): 219-230.

Wei, Y., Li, J., Zhu, C., Hao, A. \& Zhao, M. 2005. 2-O-(2hydroxybutyl)- $\beta$-cyclodextrin as a chiral selector for the capillary electrophoretic separation of chiral drugs. Analytical Sciences 21(8): 959-962.

Woolley, D.W. 1944. Some biological effects produced by benzimidazole and their reversal by purines. Journal of Biological Chemistry 152(2): 225-232.

Wu, Y.S., Lee, H.K. \& Li, S.F.Y. 2001. High-performance chiral separation of fourteen triazole fungicides by sulfated $\beta$-cyclodextrin-mediated capillary electrophoresis. Journal of Chromatography A 912(1): 171-179.

Yamamoto, C. \& Okamoto, Y. 2004. Chiral separation by HPLC using polysaccharide-based chiral stationary phases. In Chiral Separations: Methods in Molecular Biology, edited by Gübitz, G. \& Schmid, M.G. New Jersey: Humana Press. vol. 243. pp. 173-181.

Yashima, E. 2001. Polysaccharide-based chiral stationary phases for high-performance liquid chromatographic enantioseparation. Journal of Chromatography A 906(1-2): 105-125.

Ye, J., Wu, J. \& Liu, W. 2009. Enantioselective separation and analysis of chiral pesticides by high-performance liquid chromatography. TrAC Trends in Analytical Chemistry 28(10): 1148-1163.

Zhang, H., Qian, M., Wang, X., Wang, X., Xu, H., Wang, Q. \& Wang, M. 2012. HPLC-MS/MS enantioseparation of triazole fungicides using polysaccharide-based stationary phases. Journal of Separation Science 35(7): 773-777.

Zhao, M., Cui, Y., Yu, J., Xu, S. \& Guo, X. 2014. Combined use of hydroxypropyl- $\beta$-cyclodextrin and ionic liquids for the simultaneous enantioseparation of four azole antifungals by $\mathrm{CE}$ and a study of the synergistic effect. Journal of Separation Science 37(1-2): 151-157.

Zhou, Z., Li, X., Chen, X. \& Hao, X. 2010. Synthesis of ionic liquids functionalized $\beta$-cyclodextrin-bonded chiral stationary phases and their applications in high-performance liquid chromatography. Analytica Chimica Acta 678(2): 208-214.

Nurul Raihana Binti Azhari, Boon Yih Hui, Nur Nadhirah Mohamad Zain \& Noorfatimah Yahaya*

Integrative Medicine Cluster

Advanced Medical and Dental Institute (AMDI)

Universiti Sains Malaysia

13200 Penang

Malaysia

Faiz Bukhari Mohd Suah

School of Chemical Sciences

Universiti Sains Malaysia

11800 Penang

Malaysia

Sharifah Mohamad \& Muggundha Raoov

Department of Chemistry

Faculty of Science

University of Malaya

50603 Kuala Lumpur

Malaysia 
Sharifah Mohamad \& Muggundha Raoov

University of Malaya Centre for Ionic Liquids

Department of Chemistry, Faculty of Science

University of Malaya

50603 Kuala Lumpur

Malaysia
*Corresponding author; email: noorfatimah@usm.my

Received: 19 March 2020

Accepted: 12 May 2020 